\title{
Worldwide research productivity in emergency contraception: a bibliometric analysis
}

Waleed M Sweileh ${ }^{1 *}$, Sa'ed H Zyoud², Samah W Al-Jabi² and Ansam F Sawalha'

\begin{abstract}
Background: The main goal of this study was to assess worldwide research activity in emergency contraception (EC) using bibliometric indicators.

Methods: Data in SciVerse Scopus were searched for documents pertaining to emergency contraception. Data obtained were then exported to Microsoft Excel and analyzed using Statistical Package for Social Sciences.

Results: A total of 2142 documents were published about EC worldwide. Documents were written in 27 different languages and were published from 78 countries. Publications in EC started on late 1960s. Total number of citations for published EC documents was 30154 while median citation per document was six. The $h$-index of the retrieved documents was 58. The leading country in EC research was United States of America with a total of 559 documents (26.10\%). One hundred and ninety five (9.10\%) documents were published in Contraception journal. The leading institution in EC research and publications was Princeton University $(50 ; 2.33 \%)$ followed by University of California, San Francisco $(34 ; 1.59 \%)$.

Conclusions: The present data revealed that there is a worldwide increasing interest in EC research. Willingness of health policy makers to make EC accessible to the public will determine the future of EC research activity and future of EC as a contraceptive method.
\end{abstract}

Keywords: Emergency contraception, Bibliometrics, Scopus

\section{Background}

Contraception-related research has gained a lot of attention in the past few decades. The growth of population, rights of women to choose the time of motherhood, high prevalence of HIV disease, as well as the strong religious and political debate about abortion has created more attention and research momentum toward contraception science [1-4]. Furthermore, the economical and emotional burden of high rates of unintended pregnancies (UP) had drawn more attention and interest in novel and practical contraceptive methods. Historically speaking, women tried several behavioral and traditional contraceptive methods to avoid UP [5]. Currently there are several different natural, hormonal, mechanical and surgical methods for contraception that made a significant worldwide reduction in UP and illegal abortion [6-8]. However, despite the great advancement in contraception science and

\footnotetext{
* Correspondence: waleedsweileh@yahoo.com

'Department of Pharmacology/Toxicology, College of Medicine and Health Sciences, An-Najah National University, Nablus, Palestine

Full list of author information is available at the end of the article
}

technology, no contraceptive method is $100 \%$ effective in preventing pregnancy all the time [9-11]. Furthermore, women might have sexual intercourse at unexpected times or they might be forced to have sex such as in rape situations. A practical contraceptive choice for women in such situations is the use of emergency contraceptive (EC) method. There are two main types of EC methods; emergency contraceptive pills (or called morning-after pill) and Intra Uterine Devices (IUD) that are sometimes used for the purpose of EC [12-15]. Emergency contraceptive pills are available as combined estrogen and progestin pills or progestin-only (levonorgestrel) pills, or antiprogestin (ulipristal acetate or mifepristone) pills [16-19]. In early 1970s, Dr. Albert Yuzpe was the first to prescribe birth control pills for emergency contraception [20]. In 1998, the FDA approved the marketing of the first EC product. One year later, the FDA approved the first progestin-only EC named Plan $B^{\circ}[21,22]$.

Many review articles have been published about different types of contraceptive methods including emergency 
contraception [23-25]. However, scanning the literature showed no bibliometric studies about any type of contraceptive methods had been published. In contrast, hundreds of bibliometric studies in various medical fields and from different parts of the world had been published. Therefore, the goal of this bibliometric study was to assess the quantity and quality of EC-related research worldwide. Such a study will give insight into the current state of EC field. Furthermore, this study will provide baseline data for future similar projects in the field of contraception bibliometrics. So, in this study, we will give researchers in the in reproductive and family planning field an informative description of published literature about EC.

\section{Methods}

\section{Search strategy}

SciVerse Scopus, developed by Elsevier, was searched for data pertaining to EC. The choice of Scopus database was based on the fact that it is one of the largest available databases. In this study, title search strategy was applied. All subject areas in Scopus search engine including health sciences, social sciences, life sciences and physical sciences, were selected. The date range of the study was all years up to December 31st 2012. This time interval was selected to account for the time delay between the date an article is published and the date it appears within the Scopus database. Articles published after December 31st, 2012 were not consistently present within the database compared to earlier published articles., therefore articles after this date were excluded from statistical analysis. The key words used in the search query were those pertaining to emergency contraception. These key words were made after extensive review of published literature about emergency contraception. We used the following keywords: emergency contraception or postcoital contraception or morning-after-pill or emergency contraceptive pills or emergency hormonal contraception or postcoitus or post-coital contraceptive or Yuzpe or Plan B or Ulipristal acetate or levonorgestrel or intrauterine or IUD. These key words must be within articles that have the following phrase within Title/Abstract/keywords: "emergency contraception". The key words or phrases used in search engine were related to emergency contraception. These key words were present in recent review articles about emergency contraception. Documents that were published as erratum were excluded. Scopus search engine has a function that gives a summary of the types of published documents. The authors did not do a manual search for erratum documents; rather, it was given by Scopus database itself.

\section{Indices of research productivity}

Data were presented as rank order using the standard competition ranking (SCR). Only the ten top-ranked items were presented. The $h$-index, a marker of quality, was also presented. The $h$-index is the number of articles (h) that have received at least $h$ citations [26]. Quality indicators considered for the top-ten ranked journals were the journal impact factor (IF) which was evaluated using the Journal Citation Report (JCR; Web of Knowledge) 2012 science edition by Thomson Reuters (New York, NY, USA) while the second indicator was the SCImago Journal Rank (SJR) indicator (Available at: http://www.scimagojr. com/SCImagoJournalRank.pdf).

\section{Ethical approval}

The Institutional Review Board (IRB) at An-Najah National University considers that such study does not require an IRB application and approval since no human subjects are involved.

\section{Statistical analysis}

Data from Scopus were exported to Microsoft Excel ${ }^{\circ}$ and then transferred to the Statistical Package for Social Sciences, Version 15 (SPSS; SPSS Inc., Chicago, IL, USA) program for analysis. Categorical variables were expressed as Frequency and percentages. Categorical variables include document type, top 10 countries, institutions, authors and journals.

\section{Results}

Using the methodology stated above, 2163 documents about EC were retrieved. Twenty one erratum documents were excluded. Therefore, analysis was confined to 2142 documents. Of the 2142 documents, there were 1202 (56.12\%) original journal research articles, 291 (13.59\%) review articles, 187 (8.73\%) letters, 176 (8.22\%) Note, 116 (5.42) short surveys, 74 (3.45\%) editorials, 37 (1.73\%) conference papers, 54 (2.52\%) undefined documents, five $(0.23 \%)$ book chapters (Table 1$)$. Retrieved documents were written in 27 different languages and from 78 different

\begin{tabular}{lll}
$\begin{array}{l}\text { Table } \mathbf{1} \text { Types of worldwide published document about } \\
\text { EC }\end{array}$ & Number \\
\hline Document type & $\mathbf{N}=\mathbf{2 1 4 2}$ & $\%$ \\
\hline Article & 1202 & 56.12 \\
Review & 291 & 13.59 \\
Letter & 187 & 8.73 \\
Note & 176 & 8.22 \\
Short Survey & 116 & 5.42 \\
Editorial & 74 & 3.45 \\
Undefined & 54 & 2.52 \\
Conference Paper & 37 & 1.73 \\
Book Chapter & 5 & 0.23 \\
Total & $\mathbf{2 1 4 2}$ & $\mathbf{1 0 0}$ \\
\hline
\end{tabular}




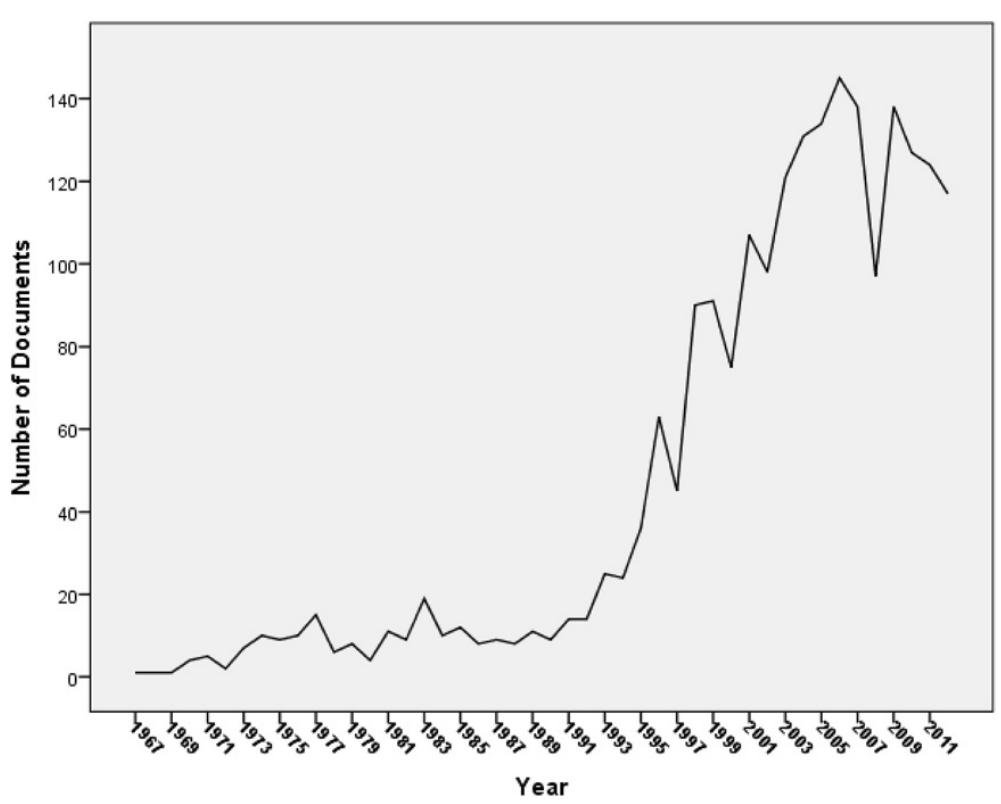

Figure 1 Worldwide growth of EC research.

countries. The main language of published documents was English (1830; 85.43\%) followed distantly by Spanish (76; 3.54\%) and French $(64 ; 3.03 \%)$ languages. The annual number of documents published about emergency contraception remained low and steady until 1990 (Figure 1). Table 2 shows top 10 countries whose researchers published most about emergency contraception. One fourth of retrieved documents were published from the USA (559; 26.10\%). India ranked third (62; 2.89\%) in emergency contraception after USA and UK. In the past 20 years, the number of retrieved articles in EC showed an obvious increase by time in USA. However, for the other top 10 countries, the number of retrieved articles remained steady and did not show an obvious increase in the past

Table 2 Top 10 countries in EC research

\begin{tabular}{lllll}
\hline SCR & Country & Number & $\%$ & World region \\
& & $\mathbf{N = 2 1 4 2}$ & & \\
\hline 1st & United States of America & 559 & 26.10 & North America \\
2nd & United Kingdom & 263 & 12.28 & EU \\
3rd & India & 62 & 2.89 & Asia \\
4th & Spain & 56 & 2.61 & EU \\
5th & France & 55 & 2.57 & EU \\
6th & Switzerland & 49 & 2.29 & E \\
7th & Germany & 43 & 2.01 & EU \\
8th & Canada & 43 & 2.01 & North America \\
9th & Australia & 39 & 1.82 & Oceania \\
10th & Chile & 37 & 1.73 & Latin America \\
\hline
\end{tabular}

Abbreviations: SCR Standard Competition Ranking, E Europe, UE European Union.
20 years (Figure 2). Seventy one documents (3.31\%) were published by African countries while 15 (0.7\%) documents were published from Middle Eastern Arab countries. The total number of citations for retrieved documents at the time of manuscript writing was 19671 with $h$-index of 58 and an average citation of 10.58 per document. In Table 3, a list of the top 10 cited documents about emergency contraception is shown [27-36]. Four of the top 10 cited articles were published in Lancet journal, 3 in New England Journal of Medicine, 1 in Human Reproduction, 1 in British Medical Journal and 1 in Journal of the American Medical Association. The highest number of citations recorded was

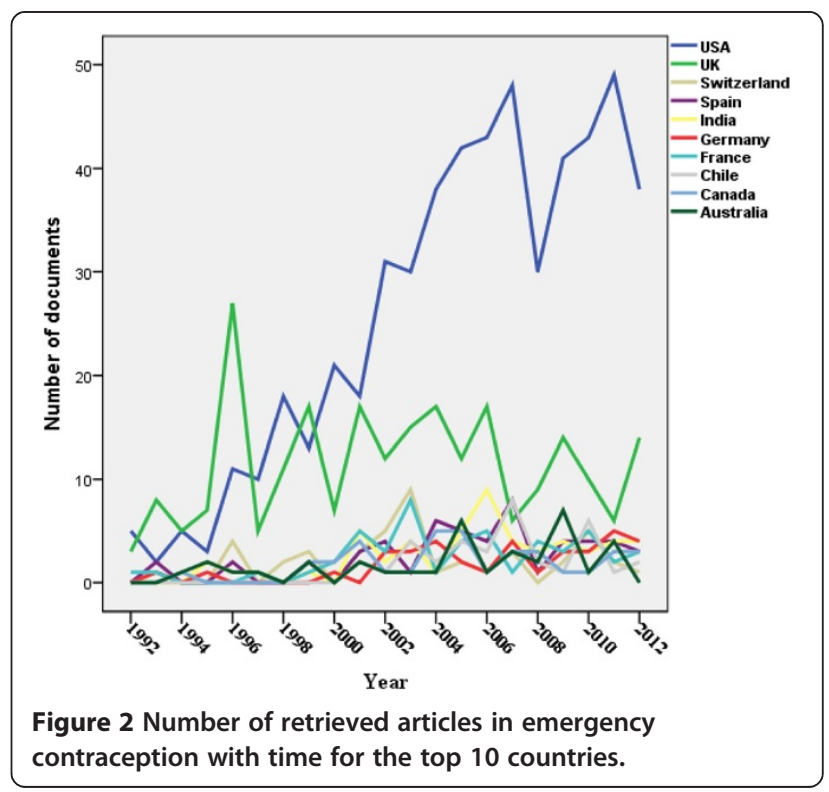


Table 3 Top 10 cited articles about EC as extracted from Scopus

\begin{tabular}{|c|c|c|c|c|}
\hline SCR & Author-Year & Title & Journal & Times cited \\
\hline $1 \mathrm{st}$ & Grimes et al. 1998 & $\begin{array}{l}\text { Randomised controlled trial of levonorgestrel versus the } \\
\text { Yuzpe regimen of combined oral contraceptives for } \\
\text { emergency contraception }\end{array}$ & Lancet & 558 \\
\hline 2nd & Von Hertzen, et al. 2002 & $\begin{array}{l}\text { Low dose mifepristone and two regimens of levonorgestrel } \\
\text { for emergency contraception: A WHO multicentre randomised trial }\end{array}$ & Lancet & 397 \\
\hline 3 rd & Glasier and Baird 1998 & The effects of self-administering emergency contraception & $\begin{array}{l}\text { New England Journal } \\
\text { of Medicine }\end{array}$ & 265 \\
\hline 4th & Glasier et al. 1992 & $\begin{array}{l}\text { Mifepristone (RU 486) compared with high-dose estrogen and } \\
\text { progestogen for emergency postcoital contraception }\end{array}$ & $\begin{array}{l}\text { New England Journal } \\
\text { of Medicine }\end{array}$ & 213 \\
\hline 5th & Piaggio et al. 1999 & $\begin{array}{l}\text { Timing of emergency contraception with levonorgestrel or the } \\
\text { Yuzpe regimen }\end{array}$ & Lancet & 210 \\
\hline 6th & Raine et al. 2005 & $\begin{array}{l}\text { Direct access to emergency contraception through pharmacies } \\
\text { and effect on unintended pregnancy and STIs: A randomized } \\
\text { controlled trial }\end{array}$ & $\begin{array}{l}\text { Journal of the } \\
\text { American Medical } \\
\text { Association }\end{array}$ & 203 \\
\hline 7th & Glasier 1997 & Emergency postcoital contraception & $\begin{array}{l}\text { New England Journal } \\
\text { of Medicine }\end{array}$ & 201 \\
\hline 8th & Ho and Kwan 1993 & $\begin{array}{l}\text { A prospective randomized comparison of levonorgestrel with } \\
\text { the Yuzpe regimen in post-coital contraception }\end{array}$ & Human Reproduction & 200 \\
\hline 9th & Von Hertzen, and Van Look 1999 & $\begin{array}{l}\text { Comparison of three single doses of mifepristone as emergency } \\
\text { contraception: A randomised trial }\end{array}$ & Lancet & 171 \\
\hline 10th & Webb et al. 1992 & $\begin{array}{l}\text { Comparison of Yuzpe regimen, danazol, and mifepristone } \\
\text { (RU486) in oral postcoital contraception }\end{array}$ & British Medical Journal & 170 \\
\hline
\end{tabular}

558 (Table 3). Table 4 shows top 10 journals in which documents about emergency contraception were published. A total of 195 (9.10\%) retrieved documents were published in the journal Contraception whereas 58 (2.71\%) were published in Journal of Family Planning and Reproductive Health Care. The leading institution in emergency contraception research and publication was Princeton University $(50 ; 2.3 \%)$ followed by University of California, San Francisco (34; 1.59\%); (Table 5). Most of the top 10 active institutions in the field of emergency contraception are based in USA and most are academic institutions. Of the 2142 documents, there were 75 documents having
Yuzpe or Plan B in the title, 33 documents having ulipristal acetate in the title, 152 documents having levonorgestrel in the title, 65 documents having intrauterine device/ IUD in the title, 118 documents having emergency contraceptive pills, and 34 documents having emergency contraception (Table 6).

\section{Discussion}

Appropriate use of contraceptive methods requires an understanding of how scientific research about efficacy and safety of various contraceptive methods has progressed. One method to assess past and current status of a

Table 4 Top 10 journals for EC publications

\begin{tabular}{|c|c|c|c|c|c|}
\hline \multirow[t]{2}{*}{ SCR } & \multirow[t]{2}{*}{ Journal } & Number & $\%$ & $\mathrm{IF}^{*}$ & SJR \\
\hline & & \multicolumn{4}{|l|}{$N=2142$} \\
\hline $1 s t$ & Contraception & 195 & 9.10 & 3.090 & 1.47 \\
\hline 2nd & Journal of Family Planning and Reproductive Health Care & 58 & 2.71 & 1.154 & 0.33 \\
\hline $3 r d$ & Obstetrics and Gynecology & 54 & 2.52 & 4.798 & 1.9 \\
\hline 4th & European Journal of Contraception and Reproductive Health Care & 41 & 1.91 & 1.808 & 0.58 \\
\hline 5th & British Journal of Family Planning & 34 & 1.59 & NA & NA \\
\hline 5th & Lancet & 34 & 1.59 & 39.060 & 7.07 \\
\hline 5th & British Medical Journal & 34 & 1.59 & 17.215 & 1.48 \\
\hline 8th & Journal of Pediatric and Adolescent Gynecology & 26 & 1.21 & 1.630 & 0.41 \\
\hline 8th & Perspectives on Sexual and Reproductive Health & 26 & 1.21 & 1.708 & 0.87 \\
\hline 9th & Human Reproduction & 25 & 1.17 & 4.670 & 2.17 \\
\hline
\end{tabular}

Abbreviations: SCR Standard Competition Ranking, NA not available, IF impact factor, SJR Standard journal ranking, NA not available, the journal was discontinued by year 2000 .

*The impact factor was reported according to Institute for Scientific Information (ISI) journal citation reports (JCR) 2012. 
Table 5 Top 10 highly productive institutions in EC research

\begin{tabular}{|c|c|c|c|c|}
\hline \multirow[t]{2}{*}{ SCR } & \multirow[t]{2}{*}{ Institution } & Number & \multirow[t]{2}{*}{$\%$} & \multirow[t]{2}{*}{ Country } \\
\hline & & $N=2142$ & & \\
\hline $1 s t$ & Princeton University & 50 & 2.33 & USA \\
\hline 2nd & University of California, San Francisco & 34 & 1.59 & USA \\
\hline 2nd & Family Health International & 34 & 1.59 & USA \\
\hline 4 th & Organisation Mondiale de la Sante & 32 & 1.49 & Switzerland \\
\hline 5th & University of Utah & 22 & 1.03 & USA \\
\hline 6th & Population Council Headquarters & 21 & 0.98 & USA \\
\hline 6th & Population Council, Mexico City & 21 & 0.98 & Mixico \\
\hline 6th & Instituto Chileno de Medicina Reproductiva & 21 & 0.98 & Chile \\
\hline 9th & University of Edinburgh & 20 & 0.93 & UK \\
\hline 10th & All India Institute of Medical Sciences & 17 & 0.79 & India \\
\hline 10th & Karolinska University Hospital & 17 & 0.79 & Sweden \\
\hline
\end{tabular}

Abbreviations: SCR Standard Competition Ranking, USA United States of America, UK United Kingdom.

particular medicine or procedure is to assess research output. As planned motherhood is now a pre-requisite for successful pregnancy and maternal health, emergency contraception has become more of a necessity for women [37-39]. Our study investigated research productivity about emergency contraception up until the year 2012 using Scopus as a search engine and as a source database. The total number of emergency contraception documents retrieved and analyzed using the methodology stated was 2142. This number represents a close approximation of worldwide research productivity in the field but definitely does not represent 100\% of global publications about emergency contraception. Scopus is considered a trustful and powerful search engine with citation analysis. However, not all journals are indexed in Scopus and therefore publications pertaining to emergency contraception in these un-indexed journals were not counted. Nevertheless, this study and up to the author's best knowledge is the first to do a bibliometric analysis of worldwide contraceptionrelated research. The finding that the $\mathrm{h}$ - indexed of

$\begin{aligned} & \text { Table } \mathbf{6} \text { Common words used as a title in the retrieved } \\
& \text { documents about emergency contraception }\end{aligned}$
\begin{tabular}{lll}
\hline No. & Word or phrase & Frequency (\%)* \\
\hline 1 & "emergency contraception" & $1436(67)$ \\
2 & "morning after" & $401(18)$ \\
3 & "levonorgestrel" & $147(6)$ \\
4 & "emergency contraceptive pills" & $118(5)$ \\
5 & "Intrauterine device" or "IUD" & $65(3)$ \\
6 & "Yuzpe" or "Plan B" & $75(3.5)$ \\
7 & "Post-coital" & $52(2)$ \\
8 & "emergency hormonal contraception" & $34(1.6)$ \\
9 & "Ulipristal acetate" & $33(1.5)$ \\
\hline
\end{tabular}

${ }^{*}$ total \% exceeds 100 because there are some overlaps in results. published emergency contraception documents is 58 indicates that there is a large audience of these published documents and citation in the regard is relatively high. There is a debate about the use of h-index as a marker of research quality. The h-index is commonly used instead of other simple bibliometric indicators like total number of papers or total number of citations. The h-index simultaneously measures the quality and quantity of scientific output. However, $h$-index measured using different databases can give different values and therefore each database has pros and cons when measuring the h-index [40-42]. Our study showed that several non-academic institutions, particularly non-profit organization, ranked among top 10 in emergency contraception research indicating that emergency contraception is a an issue of increasing interest from a demographic and family planning point of view. In addition, debate about emergency contraception and its potential abortion effect gave further momentum to research in this field. Some academic institutions have run an online website for emergency contraception awareness and directions [43]. Other institutions, like Population Council in Mexico, have dedicated their efforts to improve reproductive health through high-quality research in family planning, pregnancy-related problems including women's rights to safe and legal abortion [43]. Of the top cited documents in emergency contraception, it was clear that research groups in Edinbrugh, UK and Geneva, Switzerland have produced highly citable documents in EC field.

Our study further showed that although the prevalence of UP, HIV and sexual assaults that included rape incidences were high in Africa during civil wars, the EC research in Africa remained low [44-48]. South Africa has some research contribution in EC research that addresses awareness and services pertaining to emergency contraception [49-53]. In contrast to other world regions, EC research is limited in Arab Muslim countries in the Middle East. A 
study indicated that awareness of women in Arab world regarding emergency contraception methods was very low [54]. Another study indicated that in contrast to English EC website users, the users of Arabic EC web sites were interested in the different aspects of EC than English website users [55]. The authors of the study suggested that there is a need for creating culturally specific EC website content for health education [55].

The future of emergency contraception seems promising given the upward increase in research output in the field. In the past 2 decades, the number of documents in $\mathrm{EC}$ has increased 20 folds. The popularity and future market and clinical use of EC seems to depend on various factors including religious and political debate in addition to safety and efficacy reports. Several studies have suggested that making EC methods available will positively affect the population growth and will make the future of such method more convincing [56,57]. Definitely, the arguments concerning the mechanism of action of emergency contraception, particularly those pertaining to mifepristone, ulipristal acetate and levonorgestrel which act by inhibiting ovulation rather than implantation will overcome many religious barriers for use of EC [58]. The time course and clinical experience with emergency contraception in the past 30 years or so have shown a good safety profile of emergency contraception given to women a second chance to terminate an unwanted pregnancy [59]. Our study has few limitations that need to be listed. First of all, we used Scopus database and therefore documents published in non-Scopus-indexed journals were not included. Another limitation is that some articles did not contain the selected key words has been excluded. Therefore, the number of publications analysed in this study might not represent $100 \%$ of EC-based worldwide research activity. It should also be noted that the research output for certain institutes could have been under-estimated due to different English spelling in different articles. Therefore, such institutes might have two or more institute's profiles in Scopus because their names were written differently in different documents. Finally, some documents might be counted twice especially those presented as conference material and then published as original research articles.

\section{Conclusion}

The present data reveal a good bulk and rising trend of research activity about emergency contraception. As expected, the quantity of EC research activity was skewed toward USA and European countries. However, centres in Latin America and India have made good contribution to research in EC. Research activity and use of EC can be improved by increasing awareness and acceptability of such method among women and health policy makers.

\section{Abbreviations}

SPSS: Statistical Package for Social Sciences; ISI: Institute for Scientific Information; JCR: Journal Citation Report; IFs: impact factors; IRB: Institutional Review Board; SCR: Standard Competition Ranking; USA: United States of America; UP: Unintended pregnancies; EC: Emergency contraceptive; IUD: Intra Uterine Devices.

\section{Competing interests}

Authors declare that they have no conflict of interest in conducting this research.

\section{Authors' contributions}

All authors were involved in drafting the article, and all authors approved the final version to be submitted for publication. WS conceived of the study conception and design, organized and supervised the data collection, and provided analysis, interpretation, and writing. SZ, SA and AS participated in the study design, and provided critical revision of manuscript for important intellectual content.

\section{Acknowledgements}

The authors would like to thank An-Najah National University for giving the opportunities to access most recent information sources such as Scopus database.

\section{Author details}

'Department of Pharmacology/Toxicology, College of Medicine and Health Sciences, An-Najah National University, Nablus, Palestine. ${ }^{2}$ Department of Clinical and Community Pharmacy, College of Medicine and Health Sciences, Nablus, An-Najah National University, Nablus, Palestine.

Received: 25 July 2014 Accepted: 24 October 2014

Published: 5 May 2015

\section{References}

1. Charo RA. Warning: Contraceptive drugs may cause political headaches. N Engl J Med. 2012;366:1361-4.

2. Gordon L. Citizenship and the Right to Birth Control. Dissent. 2012;59:60-4.

3. Scharping T. Birth Control in China 1949-2000: Population policy and demographic development. London: Routledge-Curzon; 2013.

4. Butler SM, Black DR, Avery G. Emergency contraceptive pill, contraceptive, and sexually transmitted infection service availability among US college health centers. Electronic J Hum Sex. 2012. http://www.ejhs.org/volume15/ Health.html. Accessed March 182015

5. Riddle JM. Birth control. In: The Encyclopedia of Ancient History Oxford, UK. and Malden, MA: John Wiley \& Sons, Inc; 2013.

6. Foster DG, Hulett D, Bradsberry M, Darney P, Policar M. Number of oral contraceptive pill packages dispensed and subsequent unintended pregnancies. Obstet Gynecol. 2011;117:566-72.

7. Blumenthal P, Voedisch A, Gemzell-Danielsson K. Strategies to prevent unintended pregnancy: increasing use of long-acting reversible contraception. Hum Reprod Update. 2011;17:121-37.

8. Borrero S, Zite N, Potter JE, Trussell J, Smith K. Potential unintended pregnancies averted and cost savings associated with a revised Medicaid sterilization policy. Contraception. 2013:88:691-6.

9. Mansour D, Inki P, Gemzell-Danielsson K. Efficacy of contraceptive methods: a review of the literature. Eur J Contracept Reprod Health Care. 2010;15:4-16.

10. Trussell J. Contraceptive failure in the United States. Contraception. 2004;70:89-96

11. Kost K, Singh S, Vaughan B, Trussell J, Bankole A. Estimates of contraceptive failure from the 2002 National Survey of Family Growth. Contraception. 2002;2008(77):10-21.

12. Gemzell-Danielsson K. Mechanism of action of emergency contraception. Contraception. 2010;82:404-9

13. Gemzell-Danielsson K, Berger C, PGL L. Emergency contraception-mechanisms of action. Contraception. 2013;87:300-8.

14. Lalitkumar P, Berger C, Gemzell-Danielsson K. Emergency contraception. Best Pract Res Clin Endocrinol Metab. 2013;27:91-101

15. Leung WW, Levine M, Soon JA. Mechanisms of action of hormonal emergency contraceptives. Pharmacotherapy. 2010;30:158-68. 
16. Shrader SP, Hall LN, Ragucci KR, Rafie S. Updates in hormonal emergency contraception. Pharmacotherapy. 2011;31:887-95.

17. Murphy PA. Update on Emergency Contraception. J Midwifery Womens Health. 2012;57:593-602

18. Guida M, Marra M, Palatucci V, Pascale R, Visconti F, Zullo F. Emergency contraception: an updated review. Transl Med UniSa. 2011;1:271-94.

19. Duffy K, Gold MA. Adolescents and emergency contraception: update 2011. Curr Opin Obstet Gynecol. 2011;23:328-33.

20. Yuzpe AA, Thurlow H, Ramzy I, Leyshon J. Post coital contraceptionA pilot study. J Reprod Med. 1974;13:53-8.

21. Garbers S, Meserve A, Kottke M, Hatcher R, Chiasson MA. Contraceptive history, unintended pregnancy, and contraceptive method choice among urban low-income women. J Womens Health (Larchmt). 2013;22:930-7.

22. Prescott HM. The morning after: a history of emergency contraception in the United States. New Brunswick, N.J.: Rutgers University Press; 2011.

23. Richardson AR, Maltz FN. Ulipristal acetate: review of the efficacy and safety of a newly approved agent for emergency contraception. Clin Ther. 2012;34:24-36.

24. Cleland K, Zhu H, Goldstuck N, Cheng L, Trussell J. The efficacy of intrauterine devices for emergency contraception: a systematic review of 35 years of experience. Hum Reprod. 2012;27:1994-2000.

25. Westley E, Kapp N, Palermo T, Bleck J. A review of global access to emergency contraception. Int J Gynaecol Obstet. 2013;123:4-6.

26. Hirsch JE. An index to quantify an individual's scientific research output. Proc Natl Acad Sci U S A. 2005;102:16569-72.

27. Glasier A. Emergency postcoital contraception. N Engl J Med. 1997:337:1058-64

28. Glasier A, Baird D. The effects of self-administering emergency contraception. N Engl J Med. 1998:339:1-4.

29. Glasier A, Thong KJ, Dewar M, Mackie M, Baird DT. Mifepristone (RU 486) compared with high-dose estrogen and progestogen for emergency postcoital contraception. N Engl J Med. 1992;327:1041-4.

30. Grimes D, Von Hertzen H, Piaggio G, Van Look PFA. Randomised controlled trial of levonorgestrel versus the Yuzpe regimen of combined oral contraceptives for emergency contraception. Lancet. 1998;352:428-33.

31. Ho PC, Kwan MSW. A prospective randomized comparison of levonorgestrel with the Yuzpe regimen in post-coital contraception. Hum Reprod. 1993;8:389-92

32. Piaggio G, Von Hertzen $H$, Grimes DA, Van Look PFA. Timing of emergency contraception with levonorgestrel or the Yuzpe regimen. Lancet. 1999;353:721.

33. Raine TR, Harper CC, Rocca CH, Fischer R, Padian N, Klausner JD, et al. Direct access to emergency contraception through pharmacies and effect on unintended pregnancy and STIs: a randomized controlled trial. JAMA. 2005;293:54-62.

34. Von Hertzen H, Piaggio G, Ding J, Chen J, Song S, Bártfai G, et al. Low dose mifepristone and two regimens of levonorgestrel for emergency contraception: A WHO multicentre randomised trial. Lancet. 2002;360:1803-10.

35. Von Hertzen $\mathrm{H}$, Van Look PFA. Comparison of three single doses of mifepristone as emergency contraception: A randomised trial. Lancet. 1999:353:697-702.

36. Webb AMC, Russell J, Elstein M. Comparison of Yuzpe regimen, danazol, and mifepristone (RU486) in oral postcoital contraception. BMJ. 1992:305:927-31.

37. Karaçam Z, Önel K, Gerçek E. Effects of unplanned pregnancy on maternal health in Turkey. Midwifery. 2011;27:288-93.

38. Hayatbakhsh MR, Najman JM, Khatun M, Al Mamun A, Bor W, Clavarino A. A longitudinal study of child mental health and problem behaviours at 14 years of age following unplanned pregnancy. Psychiatry Res. 2011:185:200-4.

39. Singh A, Singh A, Mahapatra B. The consequences of unintended pregnancy for maternal and child health in rural India: evidence from prospective data. Matern Child Health J. 2013;17:493-500.

40. Jacsó P. The pros and cons of computing the h-index using Web of Science. Online Info Rev. 2008:32:673-88.

41. Jacsó P. The pros and cons of computing the h-index using Scopus. Online Info Rev. 2008:32:524-35.

42. Jacsó P. The pros and cons of computing the h-index using Google Scholar. Online Info Rev. 2008:32:437-52
43. Trussell J, Raymond EG. Emergency Contraception: A Last Chance to Prevent Unintended Pregnancy. 2009. http://ec.princeton.edu/questions/ec-review.pdf. Accessed October 32014

44. Feldman DA. AIDS, culture, and Africa. Gainesville, FL: University Press of Florida; 2011.

45. Baral S, Phaswana-Mafuya N. Rewriting the narrative of the epidemiology of HIV in sub-Saharan Africa. SAHARA J. 2012;9:127-30.

46. McInnes C. HIV/AIDS in sub-Saharan Africa: politics, aid and globalization. Rev of Afr Pol Econ. 2011;38:664-5.

47. Trenholm JE, Olsson P, Ahlberg BM. Battles on women's bodies: War, rape and traumatisation in eastern Democratic Republic of Congo. Glob Public Health. 2011;6:139-52.

48. Cohen DK. Female combatants and the perpetration of violence: wartime rape in the Sierra Leone Civil War. World Politics. 2013;65:383-415.

49. Hoque ME, Ghuman S. Knowledge, practices, and attitudes of emergency contraception among female university students in KwaZulu-Natal, South Africa. PLoS One. 2012;7:e46346.

50. Blanchard K, Harrison T, Sello M. Pharmacists' knowledge and perceptions of emergency contraceptive pills in Soweto and the Johannesburg Central Business District, South Africa. Int Fam Plan Perspect. 2005;31:172-8.

51. Hariparsad N. Knowledge of emergency contraception among pharmacists and doctors in Durban, South Africa. Eur J Contracept Reprod Health Care. 2001;6:21-6.

52. Roberts C, Moodley J, Esterhuizen T. Emergency contraception: knowledge and practices of tertiary students in Durban, South Africa. J Obstet Gynaecol. 2004;24:441-5.

53. Ehlers VJ. Adolescent mothers' utilization of contraceptive services in South Africa. Int Nurs Rev. 2003:50:229-41.

54. Marafie N, Ball DE, Abahussain E. Awareness of hormonal emergency contraception among married women in a Kuwaiti family social network. Eur J Obstet Gynecol Reprod Biol. 2007;130:216-22.

55. Foster AM, Wynn L, Rouhana A, Polis C, Trussell J. Reproductive health, the Arab world and the internet: usage patterns of an Arabic-language emergency contraception web site. Contraception. 2005;72:130-7.

56. Monastersky N, Landau SC. Future of emergency contraception lies in pharmacists' hands. J Am Pharm Assoc (2003). 2006;46:84-8.

57. Soon JA, Levine M, Osmond BL, Ensom MH, Fielding DW. Effects of making emergency contraception available without a physician's prescription: a population-based study. CMAJ. 2005;172:878-83.

58. Marions L, Hultenby K, Lindell I, Sun X, Ståbi B, Danielsson KG. Emergency contraception with mifepristone and levonorgestrel: mechanism of action. Obstet Gynecol. 2002;100:65-71.

59. Turner AN, Ellertson C. How safe is emergency contraception? Drug Saf. 2002:25:695-706

doi:10.1186/2054-7099-1-6

Cite this article as: Sweileh et al:: Worldwide research productivity in emergency contraception: a bibliometric analysis. Fertility Research and Practice 2015 1:6.

\section{Submit your next manuscript to BioMed Central and take full advantage of:}

- Convenient online submission

- Thorough peer review

- No space constraints or color figure charges

- Immediate publication on acceptance

- Inclusion in PubMed, CAS, Scopus and Google Scholar

- Research which is freely available for redistribution 